\title{
Benzene-Induced Aberrant miRNA Expression Profile in Hematopoietic Progenitor Cells in C57BL/6 Mice
}

\author{
Haiyan Wei ${ }^{\dagger}$, Juan Zhang ${ }^{\dagger} *$, Kehong Tan, Rongli Sun, Lihong Yin and Yuepu Pu * \\ Received: 29 September 2015 ; Accepted: 2 November 2015 ; Published: 12 November 2015 \\ Academic Editor: Martin Pichler \\ Key Laboratory of Environmental Medicine Engineering of Ministry of Education, School of Public Health, \\ Southeast University, Nanjing 210009, China; 230129497@seu.edu.cn (H.W.); 220122806@seu.edu.cn (K.T.); \\ 230109509@seu.edu.cn (R.S.); lhyin@seu.edu.cn (L.Y.) \\ * Correspondence: 101011288@seu.edu.cn (J.Z.); yppu@seu.edu.cn (Y.P.); Tel.: +86-25-8379-4996 (J.Z. \& Y.P.); \\ Fax: +86-25-8332-4322 (J.Z. \& Y.P.) \\ $\dagger$ These authors contributed equally to this work.
}

\begin{abstract}
Benzene is a common environmental pollutant that causes hematological alterations. MicroRNAs (miRNAs) may play a role in benzene-induced hematotoxicity. In this study, C57BL/6 mice showed significant hematotoxicity after exposure to $150 \mathrm{mg} / \mathrm{kg}$ benzene for 4 weeks. Benzene exposure decreased not only the number of cells in peripheral blood but also hematopoietic progenitor cells in the bone marrow. Meanwhile, RNA from Lin $^{-}$cells sorted from the bone marrow was applied to aberrant miRNA expression profile using Illumina sequencing. We found that 5 miRNAs were overexpressed and 45 miRNAs were downregulated in the benzene exposure group. Sequencing results were confirmed through qRT-PCR. Furthermore, we also identified five miRNAs which significantly altered in $\mathrm{Lin}^{-} \mathrm{c}^{-\mathrm{Kit}^{+}}$cells obtained from benzene-exposed mice, including mmu-miR-34a-5p; mmu-miR-342-3p; mmu-miR-100-5p; mmu-miR-181a-5p; and mmu-miR-196b-5p. In summary, we successfully established a classical animal model to induce significant hematotoxicity by benzene injection. Benzene exposure may cause severe hematotoxicity not only to blood cells in peripheral circulation but also to hematopoietic cells in bone marrow. Benzene exposure also alters miRNA expression in hematopoietic progenitor cells. This study suggests that benzene induces alteration in hematopoiesis and hematopoiesis-associated miRNAs.
\end{abstract}

Keywords: benzene; miRNA; hematopoietic progenitor cells

\section{Introduction}

Benzene, a ubiquitous environmental pollutant, is not only harmful to occupational workers $[1,2]$ but also poses a potential health threat to individuals who smoke cigarettes [3,4] or are living in a newly decorated house $[5,6]$. As benzene is highly volatile, it is rapidly absorbed and metabolized into various intermediate compounds, including catechol, hydroquinone, and $p$-benzoquinone $[7,8]$. Researchers found that benzene exposure could cause adverse effects, such as skin irritation, central nervous system depression, immunotoxicity and particularly hematoxicity $[9,10]$. Diseases of the hematopoietic system associated with benzene exposure include myelodysplastic syndrome, aplastic anemia, leukemia, and lymphoma [11-13].

MicroRNAs (miRNAs) may be involved in benzene-induced hematotoxicity, in addition to other well-known mechanisms, such as lipid peroxidation, apoptosis, DNA damage, and stem cell microenvironment disturbance. MiRNAs, which are endogenous non-coding RNA (19-24 nucleotide long), regulate gene expression by way of mRNA degradation or transcriptional inhibition [14] at the transcriptional or post-transcriptional level $[15,16]$. MiRNAs play important roles in multiple biological processes, including development [17], apoptosis [18,19], cell proliferation 
and differentiation [20,21], and stem cell division and development [22-24]. Alterations in miRNA expression have been found in several diseases, including solid and hematological malignancies [25,26]. However, the number of studies regarding the expression features and functions of miRNAs after exposure to exogenous pollutants is relatively lower than cancer studies $[27,28]$. Bai et al. [29] reported the aberrant miRNA profiles and mRNA expression patterns in peripheral blood cells of chronic benzene-exposed patients. As peripheral blood cells are continuously replenished from a pool of hematopoietic stem and progenitor cells (HSPCs) in bone marrow, we planned to study benzene-induced hematotoxicity and alteration in miRNAs profile in bone marrow HSPCs from benzene-exposed male C57BL/ 6 mice.

\section{Results}

\subsection{Body Weight and Organ Coefficient}

The effects of benzene exposure on body weight are shown in Figure 1. After exposure to $150 \mathrm{mg} / \mathrm{kg}$ benzene for 10 days, mice showed lower body weight than the control group $(p<0.05)$. The thymus/body weight coefficient significantly decreased, whereas the liver/body weight coefficient significantly increased (Table 1$)$ in the benzene exposure group $(p<0.05)$.

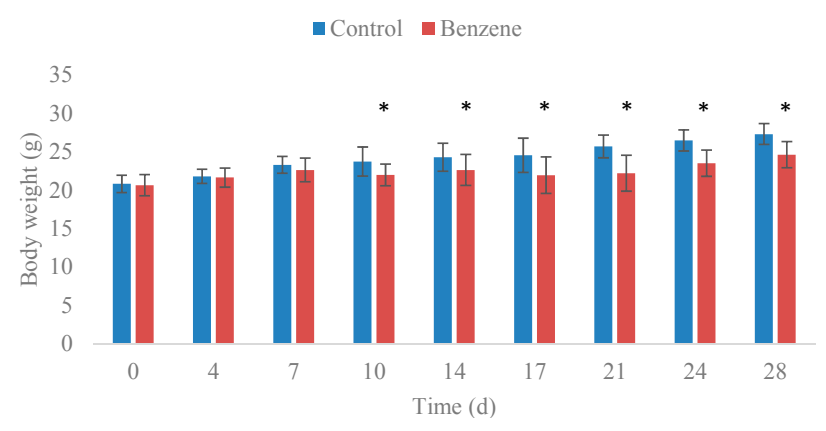

Figure 1. Effect of benzene exposure on body weight $(\mathrm{g})$. The data are presented as the mean \pm SD. $n=12$ for each group. ${ }^{*} p<0.05$.

Table 1. Effect of benzene exposure on organ coefficient.

\begin{tabular}{cccc}
\hline Group & Liver/Body Weight & Spleen/Body Weight & Thymus/Body Weight \\
\hline Control & $4.67 \pm 0.55$ & $0.38 \pm 0.10$ & $0.15 \pm 0.03$ \\
Benzene & $5.46 \pm 0.26^{*}$ & $0.32 \pm 0.12$ & $0.12 \pm 0.02{ }^{*}$ \\
\hline \multicolumn{4}{r}{ The data are presented as the mean \pm SD. $n=12$ for each group. ${ }^{*} p<0.05}$.
\end{tabular}

\subsection{Hematological Parameters}

Table 2 shows the effects of benzene exposure on blood parameters. C57BL/ 6 mice in the benzene exposure group showed decreased numbers of peripheral white blood cells, red blood cells, and lymphocytes, as well as hemoglobin concentration. By contrast, the MCV significantly increased in the benzene exposure group.

Table 2. Blood parameters of mice in benzene exposure and control groups.

\begin{tabular}{|c|c|c|c|c|c|c|c|}
\hline Group & WBC $\left(10^{9} / \mathrm{L}\right)$ & $\mathrm{RBC}\left(10^{12} / \mathrm{L}\right)$ & $\mathrm{Hb}(\mathrm{g} / \mathrm{L})$ & Plt $\left(10^{9} / \mathrm{L}\right)$ & Neut $\left(10^{9} / \mathrm{L}\right)$ & $\operatorname{Lym}\left(10^{9} / \mathrm{L}\right)$ & MCV (fL) \\
\hline Control & $8.49 \pm 1.25$ & $10.11 \pm 1.55$ & $149.34 \pm 20.53$ & $715.13 \pm 137.46$ & $1.35 \pm 0.56$ & $6.03 \pm 1.35$ & $51.98 \pm 1.15$ \\
\hline Benzene & $3.84 \pm 1.17$ * & $8.97 \pm 0.53 *$ & $136.13 \pm 8.24$ & $863.72 \pm 71.18^{*}$ & $0.99 \pm 0.39 *$ & $2.84 \pm 0.85$ * & $55.9 \pm 1.01$ * \\
\hline
\end{tabular}




\subsection{Flow Cytometric Analysis of HSPCs}

After benzene exposure for 4 weeks, we performed flow cytometric to determine enumerations of HSPCs from the bone marrow of C57BL/ 6 mice. Table 3 shows that the number of $\mathrm{Lin}^{-} \mathrm{c}-\mathrm{Kit}^{+}$cells significantly decreased in benzene-exposed mice. $(p<0.05)$.

Table 3. Effect of benzene exposure on the numbers of HSPCs.

\begin{tabular}{ccc}
\hline Group & Lin $^{-}$Cells & Lin $^{-}$c-Kit \\
& + Cells \\
\hline Control & $16026.64 \pm 3774.60$ & $2465.36 \pm 546.65$ \\
Benzene & $12339.45 \pm 6566.61$ & $1307.46 \pm 584.377^{*}$ \\
\hline
\end{tabular}

The data are presented as the mean \pm SD. $n=12$ for each group. ${ }^{*} p<0.05$.

\subsection{Aberrant miRNA Expression Based on Sequencing}

Benzene exposure produced differential expression patterns of miRNAs in C57BL/6 mice (Figure 2). The sequencing data identified 50 differentially expressed miRNAs after benzene exposure (Table $4, p<0.05$ ), of which five miRNAs were overexpressed and 45 miRNAs were downregulated. The upregulated miRNAs included mmu-miR-34a-5p, mmu-miR-129b-5p, mmu-miR-451a, mmu-miR-144-5p and mmu-miR-129b-3p, whereas highly downregulated miRNAs included mmu-miR-100-5p, mmu-miR-99a-5p, mmu-miR-33-5p, mmu-miR-125a-5p, mmu-miR-128-1-5p, mmu-miR-181b-1-3p, mmu-miR-188-5p, mmu-miR-196b-5p, mmu-miR-211-5p, mmu-miR-224-5p, mmu-miR-455-3p, mmu-miR-504-5p, mmu-miR-592-5p, mmu-miR-5107-3p, mmu-miR-5120, and mmu-let-7i-3p.

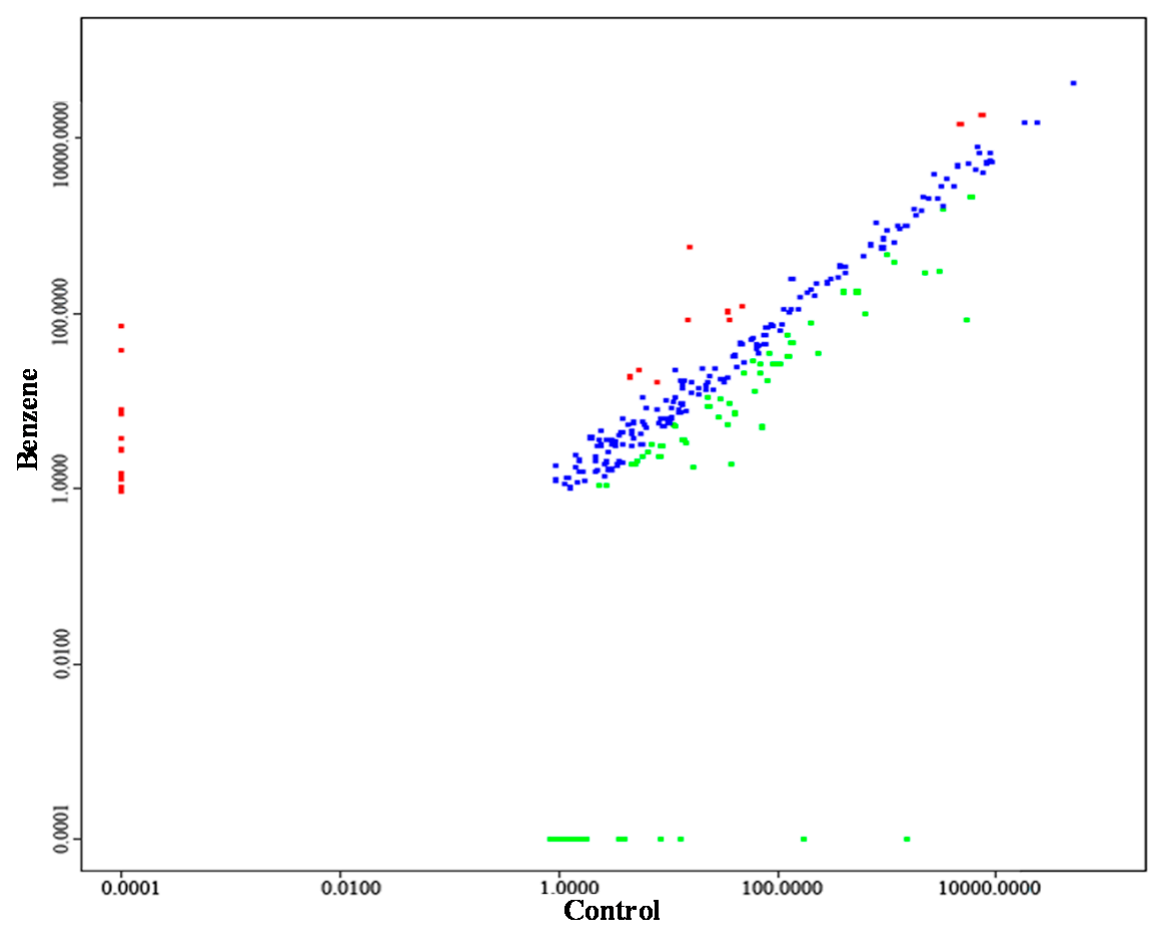

Figure 2. Scatterplot showing the relationship between the benzene exposure group and the control group. Red dots indicate the 2-fold upregulated miRNAs and green dots indicate the 2-fold downregulated miRNAs compared with the control group. Blue dots indicate no differences between two groups. $n=3$ for each group. 
Table 4. Aberrant miRNAs profile of $\mathrm{Lin}^{-}$cells expressed between benzene exposure group and the control group.

\begin{tabular}{|c|c|c|c|c|c|c|}
\hline miRNA_ID & Control & Benzene & $\begin{array}{l}\mid \log _{2}(\text { Fold } \\
\text { Change) } \mid\end{array}$ & $p$-Value & Significance-Lable & Regulation \\
\hline mmu-miR-17-3p & 83.7974 & 35.1372 & 1.253906 & 0.0114 & * & down \\
\hline mmu-miR-28a-3p & 23.3702 & 8.7843 & 1.411671 & 0.0239 & * & down \\
\hline mmu-miR-29a-3p & 121.5766 & 55.9239 & 1.120329 & 0.0201 & * & down \\
\hline mmu-miR-29c-3p & 1009.316 & 466.1916 & 1.114384 & 0.00865 & $* *$ & down \\
\hline mmu-miR-33-5p & 1.6325 & 0 & 13.9948 & 0.0475 & $*$ & down \\
\hline mmu-miR-99a-5p & 624.7338 & 97.3232 & 2.682386 & 0.000487 & $* *$ & down \\
\hline mmu-miR-99b-5p & 13.7108 & 3.5659 & 1.942975 & 0.000161 & $* *$ & down \\
\hline mmu-miR-100-5p & 2226.083 & 288.6646 & 2.947041 & 0.0000316 & $* *$ & down \\
\hline mmu-miR-125a-5p & 61.9113 & 12.6981 & 2.28559 & 0.000129 & $* *$ & down \\
\hline mmu-miR-126a-3p & 200.2112 & 77.4933 & 1.369379 & 0.00904 & ** & down \\
\hline mmu-miR-126a-5p & 30.3297 & 10.5238 & 1.527075 & 0.0106 & $*$ & down \\
\hline mmu-miR-128-1-5p & 1.4606 & 0 & 13.83427 & 0.000663 & $* *$ & down \\
\hline mmu-miR-141-3p & 90.3593 & 26.266 & 1.782477 & 0.000172 & $* *$ & down \\
\hline mmu-miR-181a-1-3p & 69.7313 & 20.508 & 1.76562 & 0.00506 & $* *$ & down \\
\hline mmu-miR-181d-5p & 1144.295 & 380.4057 & 1.588848 & 0.0000964 & ** & down \\
\hline mmu-miR-181a-5p & 5882.768 & 2099.102 & 1.486723 & 0.024 & * & down \\
\hline mmu-miR-181b-1-3p & 28.9987 & 6.5003 & 2.15741 & 0.0188 & * & down \\
\hline mmu-miR-181c-3p & 134.7541 & 46.3262 & 1.540429 & 0.0112 & * & down \\
\hline mmu-miR-188-5p & 0.9368 & 0 & 13.19353 & 0.0147 & * & down \\
\hline mmu-miR-191-5p & 3285.317 & 1517.686 & 1.114159 & 0.0473 & $*$ & down \\
\hline mmu-miR-196b-5p & 34.9694 & 5.3101 & 2.719282 & 0.000407 & $* *$ & down \\
\hline mmu-miR-199b-5p & 7.0255 & 3.2044 & 1.132547 & 0.0498 & $*$ & down \\
\hline mmu-miR-203-3p & 125.1852 & 31.8607 & 1.974214 & 0.00191 & ** & down \\
\hline $\mathrm{mmu}-\mathrm{miR}-211-5 \mathrm{p}$ & 1.117 & 0 & 13.44734 & 0.00186 & $* *$ & down \\
\hline$m m u-m i R-224-5 p$ & 8.4455 & 0 & 16.3659 & 0.000949 & $* *$ & down \\
\hline mmu-miR-324-3p & 59.3565 & 28.7012 & 1.048295 & 0.0416 & * & down \\
\hline mmu-miR-342-5p & 11.1361 & 5.3923 & 1.046271 & 0.0338 & * & down \\
\hline mmu-miR-342-3p & 403.5655 & 175.4169 & 1.202015 & 0.00359 & $* *$ & down \\
\hline mmu-miR-425-3p & 49.5631 & 20.7827 & 1.253883 & 0.024 & $*$ & down \\
\hline $\mathrm{mmu}-\mathrm{miR}-455-5 \mathrm{p}$ & 103.3616 & 26.2759 & 1.975888 & 0.0167 & * & down \\
\hline mmu-miR-455-3p & 14.3486 & 3.2959 & 2.122166 & 0.0034 & ** & down \\
\hline mmu-miR-504-5p & 3.5127 & 0 & 15.10029 & 0.000458 & $* *$ & down \\
\hline mmu-miR-592-5p & 71.7493 & 5.0445 & 3.830182 & 0.000744 & $* *$ & down \\
\hline mmu-miR-671-3p & 8.6863 & 3.0213 & 1.523572 & 0.0323 & * & down \\
\hline mmu-miR-872-5p & 68.65 & 26.0013 & 1.400676 & 0.00157 & $* *$ & down \\
\hline mmu-miR-874-3p & 5.8296 & 2.3421 & 1.315594 & 0.00755 & $* *$ & down \\
\hline mmu-miR-1291 & 5.1552 & 2.0874 & 1.304321 & 0.00577 & $* *$ & down \\
\hline mmu-miR-3060-5p & 1.1071 & 0 & 13.4345 & 0.000621 & $* *$ & down \\
\hline mmu-miR-5104 & 2.3198 & 1.0986 & 1.078334 & 0.0317 & * & down \\
\hline mmu-miR-5107-3p & 1.2706 & 0 & 13.63322 & 0.00982 & $* *$ & down \\
\hline mmu-miR-5120 & 1.1922 & 0 & 13.54134 & 0.0195 & $*$ & down \\
\hline mmu-miR-6988-3p & 5.0244 & 1.9226 & 1.385893 & 0.00503 & $* *$ & down \\
\hline mmu-miR-7043-3p & 22.7206 & 11.078 & 1.036303 & 0.00864 & $* *$ & down \\
\hline mmu-miR-7649-5p & 8.3457 & 2.3483 & 1.829416 & 0.0346 & $*$ & down \\
\hline mmu-let-7i-3p & 1.0463 & 0 & 13.35301 & 0.0185 & * & down \\
\hline$m m u-m i R-34 a-5 p$ & 15.3215 & 83.1308 & 2.439826 & 0.0075 & $* *$ & up \\
\hline mmu-miR-129b-5p & 0 & 3.7399 & 15.19071 & 0.00879 & $* *$ & up \\
\hline mmu-miR-451a & 4681.085 & 14232.5 & 1.604274 & 0.0241 & * & up \\
\hline mmu-miR-144-5p & 46.7118 & 120.2277 & 1.36391 & 0.0251 & $*$ & up \\
\hline mmu-miR-129b-3p & 4.4096 & 18.7862 & 2.090954 & 0.0211 & * & up \\
\hline
\end{tabular}

Lin $^{-}$cells from two mice were pooled as one sample, three samples per group were analyzed for miRNAs profile. $n=3$ for each group. ${ }^{*} p<0.05 .{ }^{* *} p<0.01$.

\subsection{Validation of miRNA Sequencing}

We performed qRT-PCR to confirm the sequencing results for the expression profile analysis. In agreement with the sequencing data, the expression levels of mmu-miR-129b-5p, mmu-miR-451a, mmu-miR-34a-5p and mmu-miR-144-5p increased in the benzene exposure group, whereas the levels of mmu-miR-342-3p, mmu-miR-100-5p, mmu-miR-181a-5p, and mmu-miR-196b-5p decreased in the benzene exposure group (Figure 3). Although the qRT-PCR results displayed a regulation trend similar to the sequencing data, several minor differences were found in the expression intensities 
of these two different detection methods. As observed in the sequencing data, mmu-miR-129b-5p showed the highest increase among all detected miRNAs, and the expression of this miRNA increased relatively by six-fold over the control group in qRT-PCR detection. In addition, the expression of mmu-miR-34a-5p increased by five-fold in the sequencing data and by approximately 19.55 -fold in qRT-PCR detection.

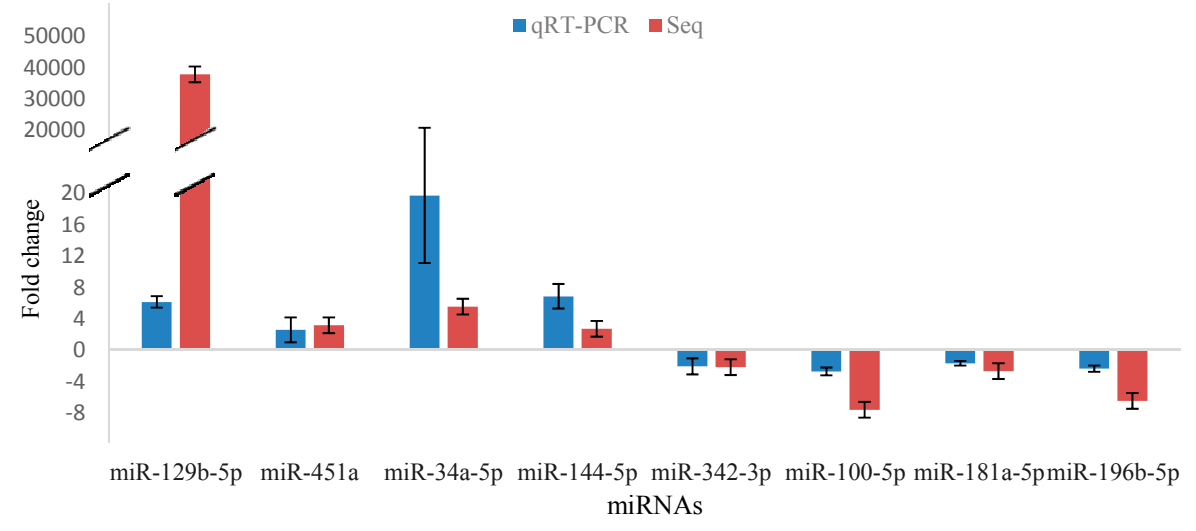

Figure 3. Confirmation of deregulated miRNAs in Lin $^{-}$cells by qRT-PCR compared with sequencing. The data are presented as the mean \pm SD. $n=6$ for each group.

\subsection{Aberrant Expression of miRNAs in $\mathrm{Lin}^{-}{ }^{-}-\mathrm{Kit}^{+}$Cells of Mice Exposed to Benzene}

We detected the expression of 8 miRNAs (mmu-miR-129b-5p, mmu-miR-451a, mmu-miR-34a-5p, mmu-miR-144-5p, mmu-miR-342-3p, mmu-miR-100-5p, mmu-miR-181a-5p, and mmu-miR-196b-5p) in in $^{-}{ }^{-}-\mathrm{Kit}^{+}$cells through qRT-PCR. Five of these miRNAs significantly changed in $\mathrm{Lin}^{-} \mathrm{c}-\mathrm{Kit}^{+}$cells of benzene-exposed mice (Figure 4). Similar results were found in $\mathrm{Lin}^{-}$ cells of benzene-exposed mice.

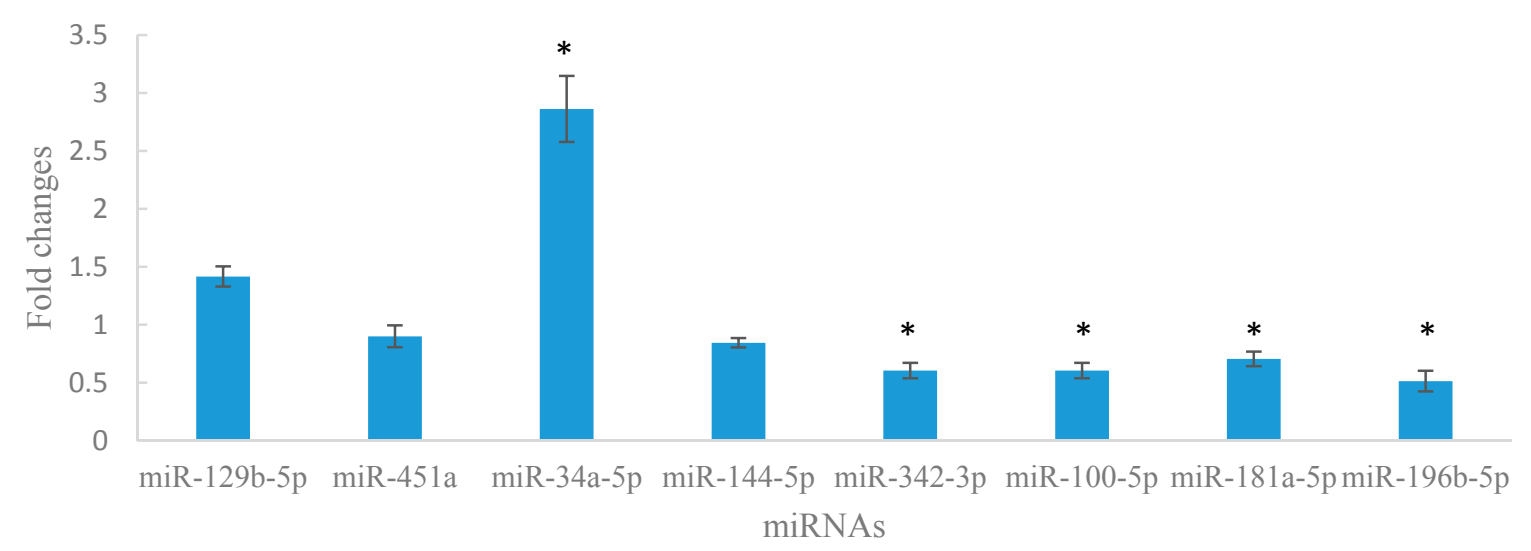

Figure 4. Significantly differential expression of miRNAs in $\mathrm{Lin}^{-} \mathrm{c}-\mathrm{Kit}^{+}$cells of mice exposed to benzene compared with the control group. The data are presented as the mean $\pm S D$. $n=4$ for each group. ${ }^{*} p<0.05$.

\section{Discussion}

As we known, benzene exposure is associated with many serious hematological malignancies [11-13]. MiRNAs play an important role in normal biological processes [17,19-24] and abnormal hematological malignancies $[18,25,26]$. However, the implication of miRNAs in benzene-induced hematotoxicity remain unclearly. Furthermore, there is no report on alteration in miRNAs profile in bone marrow HSPCs. Therefore, we plan to study 
benzene-induced hematotoxicity and alteration in the miRNA profile in bone marrow HSPCs from benzene-exposed mice.

Given the strain and gender differences reported after benzene exposure, we selected male C57BL/6 mice as the animal model for benzene exposure in this study [30-34]. Previous studies confirmed that a model induced with benzene through injection can be easily controlled and does not require the use of expensive equipment [35]. Therefore, we developed a benzene exposure model through subcutaneous injection for 4 weeks.

In this study, body weight evidently decreased after 10 days of benzene exposure. Exposure of mice to benzene led to a significant decrease in thymus/body weight. This significant decrease indicated that immunotoxicity could be induced by benzene exposure in C57BL/6 mice. A large decrease in the number of white blood cells, red blood cells, and lymphocytes, were found after benzene exposure for 4 weeks (Table 2). These results are in accordance with previous studies conducted on mice and benzene-exposed workers [35,36]. Furthermore, the number of various hematopoietic progenitor cells in mouse bone marrow also decreased in the benzene exposure group. The numbers of $\mathrm{Lin}^{-} \mathrm{c}-\mathrm{Kit}^{+}$cells showed significant decrease after benzene exposure. These results are similar to previous data and confirmed that benzene-induced hematotoxicity was specifically exhibited in HSPCs $[30,37]$. Overall, a classical animal model to induce significant hematotoxicity by benzene injection was successfully established in this study.

Previous research showed that miRNAs may participate in benzene-induced hematotoxicity in humans [29]. A research on patients with chronic benzene poisoning and healthy control showed that there was an aberrant expression of miRNAs in peripheral blood mononuclear cells. As such, we investigated differentially expressed miRNAs in HSPCs to reveal the molecular mechanisms of benzene-induced hematotoxicity. In this preliminary study, we identified a set of differentially expressed miRNAs between the benzene exposure and control groups. Subsequently, we analyzed eight of these miRNAs in $\mathrm{Lin}^{-}$cells through qRT-PCR. The results of sequencing and qRT-PCR were in the same trend. We also investigated the expression of these eight miRNAs in the $\mathrm{Lin}^{-} \mathrm{c}-\mathrm{Kit}^{+}$cells after exposure to $150 \mathrm{mg} / \mathrm{kg}$ benzene through subcutaneous injection for 4 weeks. Of these miRNAs, five miRNAs, including mmu-miR-34a-5p, mmu-miR-342-3p, mmu-miR-100-5p, mmu-miR-181a-5p and mmu-miR-196b-5p, significantly changed in mice exposed to benzene. Evidently, quantification of miRNA levels through qRT-PCR revealed several differences between $\mathrm{Lin}^{-}$cells and $\mathrm{Lin}^{-} \mathrm{c}-\mathrm{Kit}^{+}$ cells in response to benzene.

Most of the miRNAs identified in this study have been shown to be dysregulated in various hematological malignancies [38-46]. For example, in a murine chronic lymphocytic leukemia (B-CLL) model, miR-34a expression was low in the preleukemic phase but remarkably increased in the leukemic phase. Similarly, the expression of miR-34a in patients with B-CLL was 4.6-fold higher than that of healthy controls [26]. MiR-129-5p and miR-100 were obviously different between patients with acute myeloid leukemia (AML) and normal controls [39,44]. However, the expression of miR-181a in different hematological malignancies were inconsistent. MiR-181a was upregulated in AML and myelodysplastic syndromes $[47,48]$ but downregulated in multiple myeloma and chronic lymphocyte leukemia [49,50]. Furthermore, whether these miRNAs act as tumor suppressors or oncogenes remains unclear $[44,46]$. Therefore, we only described the aberrant miRNA expression profiles after benzene exposure in the present study. Further studies should be performed to verify the potential applications of these miRNAs in the prognosis and therapy of cancers.

Most of the miRNAs identified in this study have important roles in the regulation of hematopoiesis, such as in differentiation and proliferation of HSPCs. MiR-100 could promote the cell proliferation of promyelocytic blasts and block granulocyte/monocyte differentiation by targeting RBSP3 in AML [44]. Chen et al. [51] reported that miR-181 was preferentially expressed in B cells of bone marrow in mice; moreover, a tissue culture differentiation assay in mice showed that the fraction of B-lineage cells increased after ectopic expression in HSPCs. Another study revealed that miR-181 could effectively suppress the expression of Lin28 expression, disrupt the Lin28-let-7 reciprocal 
regulatory loop, upregulate Let-7, and eventually promote the differentiation of megakaryocytic. Nevertheless, miR-181 had no function on hemin-induced erythrocyte differentiation [52]. A previous microarray analysis showed that expressions of 11 miRNAs, including miR-196b, showed higher levels in the $\mathrm{Lin}^{-} \mathrm{c}-\mathrm{Kit}^{+} \mathrm{Sca}-1^{+}$compartment compared with those in total bone marrow cells; these miRNAs had functions to regulate stem cell homeostasis [53]. Meanwhile, the cluster of miR-144/451 was coexpressed from a common precursor transcript and functional cooperativity in mammalian erythropoiesis. However, an in vitro study showed that only miR-451 had functions in zebrafish erythropoiesis [23]. Another in vivo study confirmed that miR-451 played a positive role in the regulation of erythroid maturation in erythroid-differentiating K562 cells [54]. In this animal model, although the number of red blood cells significantly decreased in the benzene exposure group, the degree of decline was significantly less than that of white blood cells. No significant difference in miR-144/451 expression, which regulates the erythroid differentiation in $\mathrm{Lin}^{-} \mathrm{c}-\mathrm{Kit}^{+}$ cells, was observed.

In the present study, miR-34a expression significantly changed at different levels in hematopoietic cells, including $\mathrm{Lin}^{-}$cells and $\mathrm{Lin}^{-} \mathrm{c}-\mathrm{Kit}^{+}$cells after benzene exposure. The expression patterns are consistent with the results detected in peripheral blood cells of chronic benzene-exposed patients [29]. This finding confirmed that miR-34a may be involved in the regulation of chronic benzene poisoning.

This study provides valuable evidence on the function of miRNAs in hematopoiesis during benzene exposure. Further experiments should be performed to determine the nature of these miRNAs in the regulation mechanism of benzene toxicity.

\section{Experimental Section}

\subsection{Reagents}

Benzene, with a purity of $\geqslant 99.9 \%$, was purchased from Sigma-Aldrich (St. Louis, MO, USA). A mouse HSPC Isolation Kit (Becton Dickinson, San Jose, CA, USA) was used for flow cytometric analysis and cell sorting.

\subsection{Benzene Exposure}

Male C57BL/6 mice were housed as previously described [55]. Normal diets and water were given ad libitum throughout the study period. Mice aged 6-8 weeks old were randomly divided into two groups. One group was exposed to benzene $(150 \mathrm{mg} / \mathrm{kg})$ through subcutaneous injection once every day, 5 days per week for 4 weeks. The other group was exposed to oil solution through subcutaneous injection and designated as the normal control group. At the beginning of exposure, there was no statistical difference in the body weight of mice between the two groups. All animal procedures were carried out according to the approved protocols of the local authorizing agency for animal experiments. The protocol of experiments was reviewed and approved by the Research Ethics Committee of the Southeast University (approval number: 20140168).

\subsection{Organ Coefficient and Hematological Parameters}

The body weights of mice were recorded twice a week during the whole exposure period and each mouse was weighed after exposure. At the end of the four weeks of exposure, liver, spleen, and thymus were harvested and weighed. We calculated the ratio between organ weight and body weight as organ coefficient. To detect hematological parameters, we collected $200 \mu \mathrm{L}$ of peripheral blood from the orbital sinus of each mouse in a tube containing ethylene diamine tetraacetic acid (EDTA) after exposure. The sample was immediately analyzed using a Sysmex XE-2100 fully automatic hematology analyzer (Sysmex, Kobe, Japan). Total red blood cells (RBC), white blood cells (WBC), neutrophils (Neut), lymphocytes (Lym), platelets (Plt), the total hemoglobin $(\mathrm{Hb})$, and the mean corpuscular volume (MCV) were measured. 


\subsection{Flow Cytometric Analysis}

Bone marrow cells were harvested from limb bones (including the humerus, tibiae, and femur) of each mouse as previously described [32,56]. Briefly, both ends of the bones were cut and bone marrow cells were flushed with buffer. After centrifugation at $250 \times \mathrm{g}$ for $10 \mathrm{~min}$, bone marrow cells were suspended and adjusted to $10^{8}$ cells $/ \mathrm{mL}$. To obtain a single-cell suspension, we filtered the cells through a strainer. For detection and sorting, the cells were blocked with Fc Block (Becton Dickinson, San Jose, CA, USA) for $10 \mathrm{~min}$ at $4{ }^{\circ} \mathrm{C}$ avoiding light. Then the cells were stained with specific antibodies (PE anti-mouse c-Kit, PE-Cy7 anti-mouse Sca-1, and APC mouse lineage antibody cocktail) or the corresponding isotype controls in the dark for $45 \mathrm{~min}$ at $4{ }^{\circ} \mathrm{C}$. After washing with buffer twice and adding 7-amnioactinomycin D (7-AAD), the count for $\mathrm{Lin}^{-} \mathrm{c}$ cells and $\mathrm{Lin}^{-}{ }^{-} \mathrm{-Kit}{ }^{+}$ cells in bone marrow were analyzed with an FACS Aria ${ }^{\mathrm{TM}}$ II flow cytometer (Becton Dickinson). Primitive subpopulations were gated as shown in Figure 5. A total of 100,000 events were analyzed for each sample.
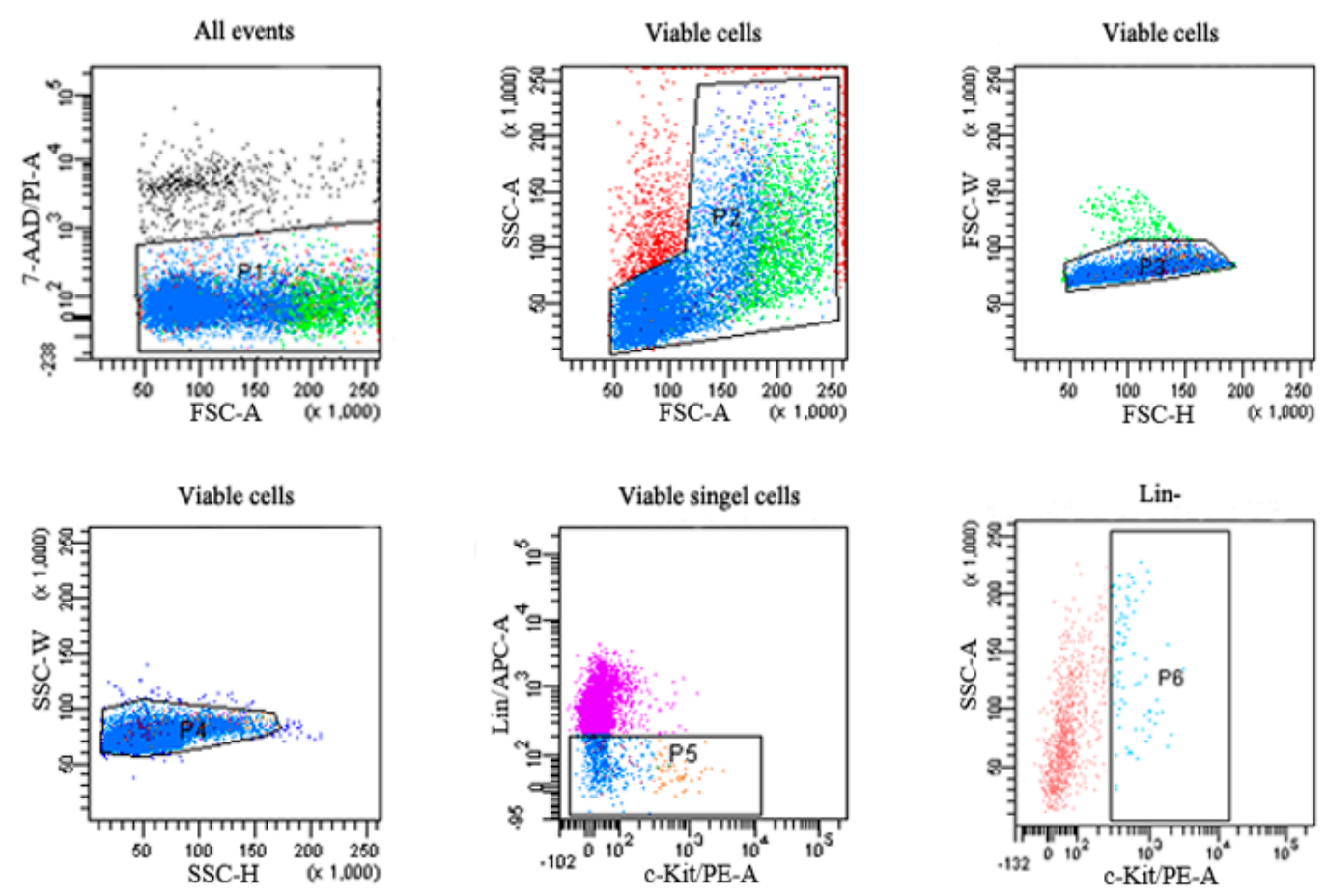

Figure 5. Gating strategy for detection and sorting various hematopoietic progenitor cells in the bone marrow by FACS. P1 is gated on the viable bone marrow cells from all events; P2 is gated on the P1-gated viable cells; P3 is gated on the P2-gated cells to remove doublets ; P4 is gated on the P3-gated cells to remove doublets; P5 is gated on Lin ${ }^{-}$c cells from P4-gated cells; P6 is gated on $\mathrm{Lin}^{-} \mathrm{c}^{-\mathrm{Kit}^{+}}$cells from P5-gated cells.

\subsection{Sorting of HSPCs through Flow Cytometry and Total RNA Extraction}

$\mathrm{Lin}^{-}$and $\mathrm{Lin}^{-} \mathrm{c}-\mathrm{Kit}^{+}$cells were obtained with the FACS Aria ${ }^{\mathrm{TM}}$ II flow cytometer (Becton Dickinson, USA) to analyze different miRNA expression profiles between the control and benzene exposure groups. To obtain sufficient cells per group for Illumina sequencing and qRT-PCR analysis, we pooled $\mathrm{Lin}^{-}$cells from two mice per group and $\mathrm{Lin}^{-}{ }^{-}-\mathrm{Kit}^{+}$cells from three mice per group. After sorting, $\mathrm{Lin}^{-}$cells as well as $\mathrm{Lin}^{-} \mathrm{c}-\mathrm{Kit}^{+}$cells were stored at $-80^{\circ} \mathrm{C}$. Within 1 month, total RNA was lysed with Trizol (Invitrogen, USA). Subsequently, RNA was separated with chloroform, precipitated with isopropyl alcohol, washed with 75\% ethanol for twice, and then dissolved in RNase-free water. 


\subsection{Illumina Sequencing of miRNAs}

The integrity of RNA was detected using the Agilent 2200 TapeStation (Agilent Technologies, Santa Clara, CA, USA). Each sample presented an RNA integrity number equivalent to high than 7.0. The purity of RNA was determined with the Nanodrop ND-1000. For all RNA samples, the ratios of A260:A280 and A260:A230 should higher than 1.8 and 2.0, respectively. Total RNA was sent to Guangzhou RioBio Co., Ltd. (Guangzhou, China) to sequence miRNA expression profiles with a Hiseq 2500 Analyzer (Illumina, San Diego, CA, USA). Briefly, RNAs were ligated with 3' RNA adapter, followed by $5^{\prime}$ adapter. Adapter-ligation RNAs were subjected to RT-PCR and amplified at a low cycle. PCR products were size-selected through PAGE according to the instructions in the TruSeq ${ }^{\circledR}$ small RNA sample prep kit (Illumina, San Diego, CA, USA). The Agilent 2200 TapeStation was used to evaluate the purified library products. The products were then diluted to $10 \mathrm{pM}$ for cluster generation in situ on the HiSeq 2500 single-end flow cell and then sequenced $(1 \times 50 \mathrm{bp})$. To obtain miRNA profiles that were significantly induced or suppressed by benzene, we set the fold change threshold of benzene exposure at $\mid \log _{2}$ (Fold Change) $\mid>1$ as compared to control for further analysis. Aberrant expression of miRNAs was determined using ANOVA.

\subsection{Verification of Sequencing through qRT-PCR Analysis}

We selected eight miRNAs that significantly changed based on the sequencing result and have been reported to be involved in processes related to hematopoiesis, and hematological malignancies including leukemia $[23,24,42,44,52,53,57]$. For qRT-PCR assay, total RNA from the pooled $\mathrm{Lin}^{-}$cells and $\mathrm{Lin}^{-} \mathrm{c}^{-\mathrm{kit}^{+}}$cells were obtained as mentioned in sorting of HSPCs through flow cytometry. We used a SYBR ${ }^{\circledR}$ PrimeScript ${ }^{\mathrm{TM}}$ miRNA RT-PCR kit (TaKaRa, Dalian, China) to detect and quantify these eight miRNAs. Briefly, the total RNA was transcribed into cDNA which was used as template for miRNA PCR array. Reverse-transcription reaction was conducted in $10 \mu \mathrm{L}$ solution containing $5 \mu \mathrm{L}$ of $2 \times$ miRNA reaction buffer mix, $2 \mu \mathrm{L}$ of RNase-free water, $1 \mu \mathrm{L}$ of miRNA PrimeScript RT enzyme mix, $1 \mu \mathrm{L}$ of $0.1 \% \mathrm{BSA}$, and $1 \mu \mathrm{L}$ of total RNA extracted from $\mathrm{Lin}^{-}$cells. The mixture was kept at $37{ }^{\circ} \mathrm{C}$ for $60 \mathrm{~min}$ and $85^{\circ} \mathrm{C}$ for $5 \mathrm{~s}$. The real-time PCR reaction was performed in a final volume of $10 \mu \mathrm{L}$ comprising $5 \mu \mathrm{L}$ of $2 \times$ SYBR premix Ex Taq II, $3 \mu \mathrm{L}$ of RNase-free water, $1 \mu \mathrm{L}$ of cDNA, $0.4 \mu \mathrm{L}$ of miRNA qPCR primer, and $0.2 \mu \mathrm{L}$ of ROX. The real-time PCR protocols included $95^{\circ} \mathrm{C}$ for $30 \mathrm{~s} ; 40$ cycles of $95^{\circ} \mathrm{C}$ for $5 \mathrm{~s}$ and $60^{\circ} \mathrm{C}$ for $30 \mathrm{~s}$; and a $4{ }^{\circ} \mathrm{C}$ holding period. All the samples were analyzed in triplicate. To calculate the relative gene expression with $2^{-\Delta \Delta C t}$ method, miRNA (U6) was used as the reference gene. To ensure specificity, the PCR products were analyzed with melting curve. The expression data for miRNA were acquired and analyzed with the StepOnePlus ${ }^{\mathrm{TM}}$ real-time PCR systems and StepOne Software v2.2.2. (Applied Biosystems, Foster, CA, USA).

\subsection{Statistical Analysis}

Data are showed as mean \pm SD. Results were first evaluated for homogeneity of variance. If the variables were homogeneous, a one-way ANOVA was performed followed by an independent sample Student's $t$ test. If the variances were not equal, the non-parametric Mann-Whitney test was employed. We considered $p<0.05$ to be significant. All results were analyzed by SPSS version 13.0 (SPSS, Chicago, IL, USA).

\section{Conclusions}

This study revealed that benzene exposure causes severe hematotoxicity and alters miRNA levels in HSPCs. The miRNA expression pattern suggests that benzene-exposed mice may undergo a series of epigenetic changes involved in regulating critical steps in the formation of HSPCs.

Acknowledgments: This work was supported by the National Natural Science Foundation of China (Grant No.: 81373034). 
Author Contributions: Haiyan Wei and Juan Zhang designed the project; Haiyan Wei, Kehong Tan, and Rongli Sun conducted the experiments; Juan Zhang, Lihong Yin, and Yuepu Pu provided technical assistance; Haiyan Wei and Juan Zhang analyzed the data and wrote the paper.

Conflicts of Interest: The authors declare no conflict of interest. 


\section{References}

1. Zhang, G.H.; Ye, L.L.; Wang, J.W.; Ren, J.C.; Xu, X.W.; Feng, N.N.; Zhou, L.F.; Ru, J.G.; Hao, Y.H.; Tian, W.; et al. Effect of polymorphic metabolizing genes on micronucleus frequencies among benzene-exposed shoe workers in China. Int. J. Hyg. Environ. Health 2014, 217, 726-732. [CrossRef] [PubMed]

2. Santiago, F.; Alves, G.; Otero, U.B.; Tabalipa, M.M.; Scherrer, L.R.; Kosyakova, N.; Ornellas, M.H.; Liehr, T. Monitoring of gas station attendants exposure to benzene, toluene, xylene (BTX) using three-color chromosome painting. Mol. Cytogenet. 2014, 7, 15. [CrossRef] [PubMed]

3. Protano, C.; Andreoli, R.; Manini, P.; Guidotti, M.; Vitali, M. A tobacco-related carcinogen: assessing the impact of smoking behaviours of cohabitants on benzene exposure in children. Tob. Control. 2012, 21, 325-329. [CrossRef] [PubMed]

4. Protano, C.; Andreoli, R.; Manini, P.; Vitali, M. Urinary trans, trans-muconic acid and S-phenylmercapturic acid are indicative of exposure to urban benzene pollution during childhood. Sci. Total Environ. 2012, 435, 115-123. [CrossRef] [PubMed]

5. Kassem, N.O.F.; Kassem, N.O.; Jackson, S.R.; Liles, S.; Daffa, R.M.; Zarth, A.T.; Younis, M.A.; Carmella, S.G.; Hofstetter, C.R.; Chatfield, D.A.; et al. Benzene Uptake in Hookah Smokers and Non-smokers Attending Hookah Social Events: Regulatory Implications. Cancer Epidemol. Biomark. 2014, 23, 2793-2809. [CrossRef] [PubMed]

6. Protano, C.; Guidotti, M.; Manini, P.; Petyx, M.; la Torre, G.; Vitali, M. Benzene exposure in childhood: Role of living environments and assessment of available tools. Environ. Int. 2010, 36, 779-787. [CrossRef] [PubMed]

7. Wang, Y.; Zhang, G.Y.; Han, Q.L.; Wang, J.; Suriguga; Li, Y.; Yu, C.H.; Li, Y.R.; Yi, Z.C. Phenolic Metabolites of Benzene Induced Caspase-Dependent Cytotoxicities to K562 Cells Accompanied with Decrease in Cell Surface Sialic Acids. Environ. Toxicol. 2014, 29, 1437-1451. [CrossRef] [PubMed]

8. Jiang, H.; Lai, Y.M.; Hu, K.Q.; Wei, Q.Z.; Liu, Y.G. Human CYP2E1-dependent and human sulfotransferase 1A1-modulated induction of micronuclei by benzene and its hydroxylated metabolites in Chinese hamster V79-derived cells. Mutat. Res. 2014, 770, 37-44. [CrossRef] [PubMed]

9. Shen, M.; Zhang, L.P.; Lee, K.M.; Vermeulen, R.; Hosgood, H.D.; Li, G.L.; Yin, S.N.; Rothman, N.; Chanock, S.; Smith, M.T.; et al. Polymorphisms in genes involved in innate immunity and susceptibility to benzene-induced hematotoxicity. Exp. Mol. Med. 2011, 43, 374-378. [CrossRef] [PubMed]

10. Li, B.; Niu, Y.Z.; Liu, S.C.; Yu, W.; Chen, J.Y.; Wu, L.; Liu, W.W.; Chen, S.H.; Yang, L.J.; Li, Y.Q. A change in $\mathrm{CD} 3 \gamma, \mathrm{CD} 3 \delta, \mathrm{CD} 3 \varepsilon$, and $\mathrm{CD} 3 \zeta$ gene expression in T-lymphocytes from benzene-exposed and benzene-poisoned workers. J. Immunotoxicol. 2012, 9, 160-167. [CrossRef] [PubMed]

11. Jiao, J.; Zheng, T.; Lan, Q.; Chen, Y.; Deng, Q.; Bi, X.; Kim, C.; Holford, T.; Leaderer, B.; Boyle, P.; et al. Occupational solvent exposure, genetic variation of DNA repair genes, and the risk of non-Hodgkin's lymphoma. Eur. J. Cancer Prev. 2012, 21, 580-584. [CrossRef] [PubMed]

12. Schnatter, A.R.; Glass, D.C.; Tang, G.; Irons, R.D.; Rushton, L. Myelodysplastic syndrome and benzene exposure among petroleum workers: an international pooled analysis. J. Natl. Cancer Inst. 2012, 104, 1724-1737. [CrossRef] [PubMed]

13. Vlaanderen, J.; Lan, Q.; Kromhout, H.; Rothman, N.; Vermeulen, R. Occupational benzene exposure and the risk of chronic myeloid leukemia: a meta-analysis of cohort studies incorporating study quality dimensions. Am. J. Ind. Med. 2012, 55, 779-785. [CrossRef] [PubMed]

14. Ding, X.C.; Weiler, J.; Grosshans, H. Regulating the regulators: mechanisms controlling the maturation of microRNAs. Trends Biotechnol. 2009, 27, 27-36. [CrossRef] [PubMed]

15. Lim, L.P.; Lau, N.C.; Garrett-Engele, P.; Grimson, A.; Schelter, J.M.; Castle, J.; Bartel, D.P.; Linsley, P.S.; Johnson, J.M. Microarray analysis shows that some microRNAs downregulate large numbers of target mRNAs. Nature 2005, 433, 769-773. [CrossRef] [PubMed]

16. Bartel, D.P. MicroRNAs: genomics, biogenesis, mechanism, and function. Cell 2004, 116, $281-297$. [CrossRef]

17. Reinhart, B.J.; Slack, F.J.; Basson, M.; Pasquinelli, A.E.; Bettinger, J.C.; Rougvie, A.E.; Horvitz, H.R.; Ruvkun, G. The 21-nucleotide let-7 RNA regulates developmental timing in Caenorhabditis elegans. Nature 2000, 403, 901-906. [PubMed] 
18. Calin, G.A.; Ferracin, M.; Cimmino, A.; di Leva, G.; Shimizu, M.; Wojcik, S.E.; Iorio, M.V.; Visone, R.; Sever, N.I.; Fabbri, M.; et al. A MicroRNA signature associated with prognosis and progression in chronic lymphocytic leukemia. N. Engl. J. Med. 2005, 353, 1793-1801. [CrossRef] [PubMed]

19. Cheng, A.M.; Byrom, M.W.; Shelton, J.; Ford, L.P. Antisense inhibition of human miRNAs and indications for an involvement of miRNA in cell growth and apoptosis. Nucleic Acids Res. 2005, 33, 1290-1297. [CrossRef] [PubMed]

20. Saal, S.; Harvey, S.J. MicroRNAs and the kidney: coming of age. Curr. Opin. Nephrol. Hypertens. 2009, 18, 317-323. [CrossRef] [PubMed]

21. Liang, Y.; Ridzon, D.; Wong, L.; Chen, C. Characterization of microRNA expression profiles in normal human tissues. BMC Genom. 2007, 8, 166. [CrossRef] [PubMed]

22. Hatfield, S.; Ruohola-Baker, H. microRNA and stem cell function. Cell Tissue Res. 2008, 331, 57-66. [CrossRef] [PubMed]

23. Papapetrou, E.P.; Korkola, J.E.; Sadelain, M. A genetic strategy for single and combinatorial analysis of miRNA function in mammalian hematopoietic stem cells. Stem Cells 2010, 28, 287-296. [CrossRef] [PubMed]

24. Liao, R.; Sun, J.; Zhang, L.; Lou, G.; Chen, M.; Zhou, D.; Chen, Z.; Zhang, S. MicroRNAs play a role in the development of human hematopoietic stem cells. J. Cell. Biochem. 2008, 104, 805-817. [CrossRef] [PubMed]

25. Ebrahimi, F.; Gopalan, V.; Smith, R.A.; Lam, A.K. miR-126 in human cancers: clinical roles and current perspectives. Exp. Mol. Pathol. 2014, 96, 98-107. [CrossRef] [PubMed]

26. Asslaber, D.; Pinon, J.D.; Seyfried, I.; Desch, P.; Stocher, M.; Tinhofer, I.; Egle, A.; Merkel, O.; Greil, R. microRNA-34a expression correlates with MDM2 SNP309 polymorphism and treatment-free survival in chronic lymphocytic leukemia. Blood 2010, 115, 4191-4197. [CrossRef] [PubMed]

27. Zhang, B.; Pan, X. RDX induces aberrant expression of microRNAs in mouse brain and liver. Environ. Health Perspect. 2009, 117, 231-240. [CrossRef] [PubMed]

28. Zhang, Y.; Wang, X.; Fu, Y.; Yin, L.; Pu, Y.; Liang, G. Expression profiling and pathway analysis of microRNA expression in the lungs of mice exposed to long-term, low-dose benzo(a)pyrene. Mol. Cell. Toxicol. 2014, 10, 67-74. [CrossRef]

29. Bai, W.; Chen, Y.; Yang, J.; Niu, P.; Tian, L.; Gao, A. Aberrant miRNA profiles associated with chronic benzene poisoning. Exp. Mol. Pathol. 2014, 96, 426-430. [CrossRef] [PubMed]

30. Takahashi, M.; Tsujimura, N.; Yoshino, T.; Hosokawa, M.; Otsuka, K.; Matsunaga, T.; Nakasono, S. Assessment of benzene-induced hematotoxicity using a human-like hematopoietic lineage in NOD/Shi-scid/IL-2Rgammanull mice. PLoS ONE 2012, 7, e50448. [CrossRef] [PubMed]

31. Bauer, A.K.; Faiola, B.; Abernethy, D.J.; Marchan, R.; Pluta, L.J.; Wong, V.A.; Gonzalez, F.J.; Butterworth, B.E.; Borghoff, S.J.; Everitt, J.I.; et al. Male mice deficient in microsomal epoxide hydrolase are not susceptible to benzene-induced toxicity. Toxicol. Sci. 2003, 72, 201-209. [CrossRef] [PubMed]

32. Faiola, B.; Bauer, A.K.; Fuller, E.S.; Wong, V.A.; Pluta, L.J.; Abernethy, D.J.; Mangum, J.B.; Everitt, J.I.; Recio, L. Variations in Prkdc and susceptibility to benzene-induced toxicity in mice. Toxicol. Sci 2003, 75, 321-332. [CrossRef] [PubMed]

33. Inoue, T.; Hirabayashi, Y. Hematopoietic neoplastic diseases develop in $\mathrm{C} 3 \mathrm{H} / \mathrm{He}$ and $\mathrm{C} 57 \mathrm{BL} / 6$ mice after benzene exposure: strain differences in bone marrow tissue responses observed using microarrays. Chem. Biol. Interact. 2010, 184, 240-245. [CrossRef] [PubMed]

34. Kawasaki, Y.; Hirabayashi, Y.; Kaneko, T.; Kanno, J.; Kodama, Y.; Matsushima, Y.; Ogawa, Y.; Saitoh, M.; Sekita, K.; Uchida, O.; et al. Benzene-induced hematopoietic neoplasms including myeloid leukemia in Trp53-deficient C57BL/6 and C3H/He mice. Toxicol. Sci. 2009, 110, 293-306. [CrossRef] [PubMed]

35. Huang, J.S.; Zhao, M.D.; Shi, J.M.; Zhang, J.H.; Li, B.; Fan, W.; Zhou, Y.L. Expression of multidrug resistance 1 and multidrug resistance-related protein 1 in C57BL/6 mice treated with benzene. Genet. Mol. Res. 2013, 12, 5842-5850. [CrossRef] [PubMed]

36. Kuang, S.; Liang, W. Clinical analysis of 43 cases of chronic benzene poisoning. Chem. Biol. Interact. 2005, 153, 129-135. [CrossRef] [PubMed]

37. Hirabayashi, Y.; Inoue, T. Benzene-induced bone-marrow toxicity: a hematopoietic stem-cell-specific, aryl hydrocarbon receptor-mediated adverse effect. Chem. Biol. Interact. 2010, 184, 252-258. [CrossRef] [PubMed] 
38. Hedstrom, G.; Thunberg, U.; Berglund, M.; Simonsson, M.; Amini, R.M.; Enblad, G. Low expression of microRNA-129-5p predicts poor clinical outcome in diffuse large B cell lymphoma (DLBCL). Int. J. Hematol. 2013, 97, 465-471. [CrossRef] [PubMed]

39. Zhi, F.; Cao, X.; Xie, X.; Wang, B.; Dong, W.; Gu, W.; Ling, Y.; Wang, R.; Yang, Y.; Liu, Y. Identification of circulating microRNAs as potential biomarkers for detecting acute myeloid leukemia. PLoS ONE 2013, 8, e56718. [CrossRef] [PubMed]

40. Svasti, S.; Masaki, S.; Penglong, T.; Abe, Y.; Winichagoon, P.; Fucharoen, S.; Umemura, T. Expression of microRNA-451 in normal and thalassemic erythropoiesis. Ann. Hematol. 2010, 89, 953-958. [CrossRef] [PubMed]

41. Asmar, F.; Hother, C.; Kulosman, G.; Treppendahl, M.B.; Nielsen, H.M.; Ralfkiaer, U.; Pedersen, A.; Moller, M.B.; Ralfkiaer, E.; de Nully Brown, P.; et al. Diffuse large B-cell lymphoma with combined TP53 mutation and MIR34A methylation: Another "double hit" lymphoma with very poor outcome? Oncotarget 2014, 5, 1912-1925. [CrossRef] [PubMed]

42. De Marchis, M.L.; Ballarino, M.; Salvatori, B.; Puzzolo, M.C.; Bozzoni, I.; Fatica, A. A new molecular network comprising PU.1, interferon regulatory factor proteins and miR-342 stimulates ATRA-mediated granulocytic differentiation of acute promyelocytic leukemia cells. Leukemia 2009, 23, 856-862. [CrossRef] [PubMed]

43. Coskun, E.; Neumann, M.; Schlee, C.; Liebertz, F.; Heesch, S.; Goekbuget, N.; Hoelzer, D.; Baldus, C.D. MicroRNA profiling reveals aberrant microRNA expression in adult ETP-ALL and functional studies implicate a role for miR-222 in acute leukemia. Leuk. Res. 2013, 37, 647-656. [CrossRef] [PubMed]

44. Zheng, Y.S.; Zhang, H.; Zhang, X.J.; Feng, D.D.; Luo, X.Q.; Zeng, C.W.; Lin, K.Y.; Zhou, H.; Qu, L.H.; Zhang, P.; et al. MiR-100 regulates cell differentiation and survival by targeting RBSP3, a phosphatase-like tumor suppressor in acute myeloid leukemia. Oncogene 2012, 31, 80-92. [CrossRef] [PubMed]

45. Akbari Moqadam, F.; Lange-Turenhout, E.A.; Aries, I.M.; Pieters, R.; den Boer, M.L. MiR-125b, miR-100 and miR-99a co-regulate vincristine resistance in childhood acute lymphoblastic leukemia. Leuk. Res. 2013, 37, 1315-1321. [CrossRef] [PubMed]

46. Lin, S.; Pan, L.; Guo, S.; Wu, J.; Jin, L.; Wang, J.C.; Wang, S. Prognostic role of microRNA-181a/b in hematological malignancies: a meta-analysis. PLoS ONE 2013, 8, e59532. [CrossRef] [PubMed]

47. Debernardi, S.; Skoulakis, S.; Molloy, G.; Chaplin, T.; Dixon-McIver, A.; Young, B.D. MicroRNA miR-181a correlates with morphological sub-class of acute myeloid leukaemia and the expression of its target genes in global genome-wide analysis. Leukemia 2007, 21, 912-916. [CrossRef] [PubMed]

48. Pons, A.; Nomdedeu, B.; Navarro, A.; Gaya, A.; Gel, B.; Diaz, T.; Valera, S.; Rozman, M.; Belkaid, M.; Montserrat, E.; et al. Hematopoiesis-related microRNA expression in myelodysplastic syndromes. Leuk. Lymphoma 2009, 50, 1854-1859. [CrossRef] [PubMed]

49. Pichiorri, F.; Suh, S.S.; Ladetto, M.; Kuehl, M.; Palumbo, T.; Drandi, D.; Taccioli, C.; Zanesi, N.; Alder, H.; Hagan, J.P.; et al. MicroRNAs regulate critical genes associated with multiple myeloma pathogenesis. Proc. Natl. Acad. Sci. USA 2008, 105, 12885-12890. [CrossRef] [PubMed]

50. Zhu, D.X.; Zhu, W.; Fang, C.; Fan, L.; Zou, Z.J.; Wang, Y.H.; Liu, P.; Hong, M.; Miao, K.R.; Liu, P.; et al. miR-181a/b significantly enhances drug sensitivity in chronic lymphocytic leukemia cells via targeting multiple anti-apoptosis genes. Carcinogenesis 2012, 33, 1294-1301. [CrossRef] [PubMed]

51. Chen, C.Z.; Li, L.; Lodish, H.F.; Bartel, D.P. MicroRNAs modulate hematopoietic lineage differentiation. Science 2004, 303, 83-86. [CrossRef] [PubMed]

52. Li, X.; Zhang, J.; Gao, L.; McClellan, S.; Finan, M.A.; Butler, T.W.; Owen, L.B.; Piazza, G.A.; Xi, Y. MiR-181 mediates cell differentiation by interrupting the Lin28 and let-7 feedback circuit. Cell Death Differ. 2012, 19, 378-386. [CrossRef] [PubMed]

53. O'Connell, R.M.; Chaudhuri, A.A.; Rao, D.S.; Gibson, W.S.; Balazs, A.B.; Baltimore, D. MicroRNAs enriched in hematopoietic stem cells differentially regulate long-term hematopoietic output. Proc. Natl. Acad. Sci. USA 2010, 107, 14235-14240. [CrossRef] [PubMed]

54. Bruchova-Votavova, H.; Yoon, D.; Prchal, J.T. miR-451 enhances erythroid differentiation in K562 cells. Leuk. Lymphoma 2010, 51, 686-693. [CrossRef] [PubMed]

55. Wei, H.Y.; Tan, K.H.; Sun, R.L.; Yin, L.H.; Zhang, J.; Pu, Y.P. Aberrant Production of Th1/Th2/Th17-Related Cytokines in Serum of C57BL/6 Mice after Short-Term Formaldehyde Exposure. Int. J. Environ. Res. Public Health 2014, 11, 10036-10050. [CrossRef] [PubMed] 
56. Zhu, J.; Wang, H.; Yang, S.; Guo, L.Q.; Li, Z.; Wang, W.; Wang, S.H.; Huang, W.T.; Wang, L.P.; Yang, T.; et al. Comparison of toxicity of benzene metabolite hydroquinone in hematopoietic stem cells derived from murine embryonic yolk sac and adult bone marrow. PLoS ONE 2013, 8, e71153. [CrossRef] [PubMed]

57. Navarro, F.; Gutman, D.; Meire, E.; Caceres, M.; Rigoutsos, I.; Bentwich, Z.; Lieberman, J. miR-34a contributes to megakaryocytic differentiation of K562 cells independently of p53. Blood 2009, 114, 2181-2192. [CrossRef] [PubMed]

(c) (C) 2015 by the authors; licensee MDPI, Basel, Switzerland. This article is an open access article distributed under the terms and conditions of the Creative Commons by Attribution (CC-BY) license (http:/ / creativecommons.org/licenses/by/4.0/). 